\title{
RUSSIAN DESMAN (DESMANA MOSCHATA: TALPIDAE) AT THE EDGE OF DISAPPEARANCE
}

\author{
Marina V. Rutovskaya ${ }^{1}$, Maria V. Onufrenya ${ }^{2}$, Alexander S. Onufrenya ${ }^{2}$ \\ ${ }^{1} A . N$. Severtsov Institute of Ecology and Evolution of RAS, Russia \\ ${ }^{2}$ Oka State Nature Biosphere Reserve, Russia \\ e-mail:desmana@yandex.ru
}

Received: 30.03.2017

\begin{abstract}
The population of the Russian desman in all historical areas is currently no more than $8000-10,000$ individuals. The estimated population size of the Russian desman is based on direct surveys during 2010-2016. We observed over 266 $\mathrm{km}$ of the coastline in eight regions where the desman lives. Since the early $20^{\text {th }}$ century the number of specimens has been steadily declining. In addition to the previously described factors that determine the reduction of the population size, such as land reclamation, the construction of hydroelectric stations and the flourishing of poaching at the end of the last century, the status of the Russian desman population is adversely affected by periodic droughts and the absence of floods. Currently Protected Areas remain as the only passive measure to protect the Russian desman in the absence of a programme to species protection nor state support.
\end{abstract}

Key words: animals from the Red Data Book, conservation management, Russian desman

\section{Introduction}

The Russian desman takes a very ambiguous position among protected rare species. On the one hand, it is listed in the Red Data Book of the Russian Federation (2001), currently with the status of declining species (status 2) and the Red List of IUCN (status - Vulnerable species) (Kennerley \& Turvey, 2016). On the other hand, currently, there are not any efforts to protect this unique animal. And most of the works devoted to its monitoring and conservation are based on enthusiasm of individual researchers. Meanwhile, the desman is a relict species of the central part of Russia. And only small areas of Ukraine and Kazakhstan were inhabited by desmans (Borodin, 1963). Having lost its commercial value, the desman remains an interesting object for scientific studies and a species that we can lose in the near future.

The ancient range of the desman, judging by the finds of fossil remains, was much wider than the modern one, and probably it covered the entire territory of Europe up to the Ural (Borodin, 1963; RzebikKowalska, 2006; Smirnov \& Ponomarev, 2007). In the past, the fauna of desmans was much richer in species (Borodin, 1963). By the end of the $19^{\text {th }}$ century, two species remained in Europe: the Pyrenean desman (Galemys pyrenaicus Geoffroy, 1811) and the Russian desman (Desmana moschata Linnaeus, 1758) (Fig. 1). The first one lives in the mountain rivers of the Pyrenees at the territory of Spain, France and Portugal. The second desman occurs only in floodplain lakes and slowly flowing rivers in the Volga, Dnieper, Don, and Urals basins. The animal arranges burrows at steep banks of reservoirs, and finds food by swimming along the bottom. Reproduction and abundance of the species depends on the presence of floods. Too high floods, when Desmana moschata does not have access temporarily to their nests, and winter floods, when inhabited burrows are flooded with water, and the animal is not able to reach the surface, lead to death of a significant part of the populations (Borodin, 1963). In contrast, low floods or their absence limit the reproduction of desman and, as a consequence, lead to a reduction in its numbers, too (Rutovskaya et al., 2012).

The last century the number of the Russian desman has tended only to decrease. At the beginning of the $20^{\text {th }}$ century, the resource of the species can only be estimated by the volume of skins. L.P. Borodin (1963) gives two versions of harvesting volume of desmans in the late $19^{\text {th }}$ and early $20^{\text {th }}$ century: 5500-20,000 skins per year, according to N.M. Kulagin (1922), and from 50,000 to 100,000 skins, according to L.V. Shaposhnikov (1938), P.I. Borovitsky (1951) and B.A. Kuznetsov (1932). Up to 60,000 of desman skins were represented at the fair that was held in Nizhny Novgorod in 1913 (Kulagin, 1922). The harvesting of desmans had stopped by 1914, because of the Desmana moschata population depression and the political situation in the country.

Since the desman resource has not restored during the First World War and the Civil Wars, the Soviet government everywhere banned its harvesting in 1920. This restriction was only for one year1933, during which about 19,000 skins were gath- 
ered (Borodin, 1963). The licensing catching of the desman was permitted in 1940 to 1956 , and over 175,000 animals were withdrawn during these 16 years, including 22,000 skins during 1953. Since 1956, a complete ban on the Desmana moschata catching has been introduced (Borodin, 1963).

The first general quantitative evaluation of the species we find in the monograph by Khakhin \& Ivanov (1990): in 1970 the desman resource was estimated at 70,900 individuals by surveys that were conducted by the method of Borodin (1960). A complete ban on Russian desman catching and even including this species into the Red Data Book of USSR (1978) did not stabilise its number. The total desman resource was estimated at only 40,800 individuals by 1985 (Khakhin \& Ivanov, 1990).

The Department for the Conservation and Development of Hunting Resources, at the request of the Biodiversity Conservation Centre, has carried out a survey of the Russian desman reservoirs throughout the historic range in 2000-2001. And a further decrease in the desman number was noticed: 28,000 animals. In 2005 the number of species was estimated only at 25,000 individuals, according to polling data (Khakhin, 2009).

M.V. Onufrenya, an employee of the Oka State Nature Reserve, organised another poll in 2006-2009: 37 federal Protected Areas within the desman range were surveyed. But only 7 Reserves and National Parks gave a positive response. Sepa- rate surveys in a number of Protected Areas showed a catastrophic decline in the species number. And the desman resource was estimated only at 4000 individuals in 2010 (Onufrenya et al., 2011).

I.G. Pidoplichko (1951) explains the range narrowing and extinction of some European desman species of Germany, Poland, southern Sweden, southern Belarus and Western Ukraine, due to paleogeographic changes before the emergence of anthropological factors in the $19^{\text {th }}$ century. Unfavourable changes were the regular winter floods on rivers, freezing of shallow water bodies to the bottom, as well as large summer droughts, accompanied by the shoaling of rivers. According to this author, such hydrographic conditions were aroused in the middle zone of Europe by formation of the Baltic-White Sea basin in the Pleistocene.

The reduction of the Russian desman area in the late $19^{\text {th }}$ and beginning of the $20^{\text {th }}$ century is associated, first of all, with an anthropogenic impact, especially with active deforestation. The sharp decline at forest areas significantly influenced the climate and hydrography of the country. Many watershed forests have disappeared. Many forest rivers have turned into treeless areas and became shallow or dried up. The level of groundwater has markedly decreased in vast swamped areas. This circumstance can be considered to be the primary cause of the increasing process of the desman population degradation (Borodin, 1963).

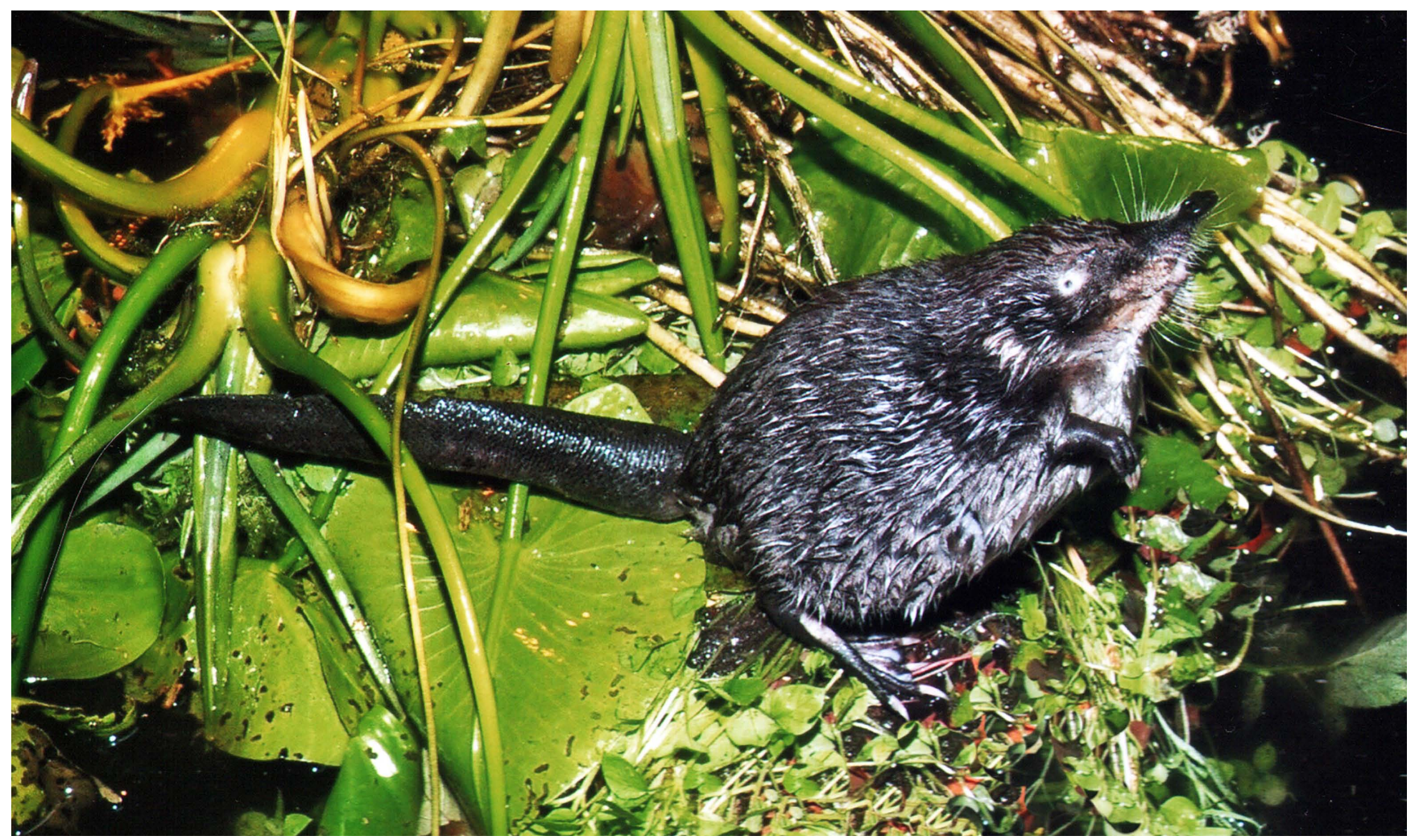

Fig. 1. Russian Desman (Desmana moschata) - rare endemic animal species (Photo: Klaus Rudloff). 
Simultaneously with deforestation, an active development of land reclamation began: irrigation of dry lands and drainage of marshes. Before the October Revolution in 1917 in Russia, the area of drained land amounted to 320,000 square kilometres. Drainage melioration was applied in the central provinces - the original area of the Russian desman. Soon after the establishment of the Soviet government, this work was resumed. In the project of Russian electrification - GOELRO - there was a special section «Melioration and electrification», prepared by the professors A.M. Dmitriev and A.N. Kostyakov. This project had provided for draining of 300,000-400,000 square kilometres of lands (Kolpakov \& Sukharev, 1981).

A large-scale reclamation engineering was deployed after the USSR Government Decrees adopted in 1966 and 1984. And by 1990 the area of reclaimed lands has amounted to 112,700 square kilometres. Although the area of reclaimed land was reduced over the years of restructuring (Aidarov, 2006), the restoration of shallow water bodies has not observed.

The melioration of agricultural lands is still in progress. From 2006 to 2013, the federal target programme «Fertility» has operated in our country (Government Decree №99 of February 20, 2006). And currently it has been replaced by a new state programme - «Development of the Reclamation of Agricultural Land in Russia for 2014-2020» (Resolution №922 of October 12, 2013). Thus, agriculture development and the increase in acreage remain a negative factor for the Russian desman population through degrading its original habitat (Okulova et al., 2008).

The construction of a network of hydro-electric power stations on the Volga became the largest scale reduction of the species resource.

The first dam on the Volga was planned to be constructed at the gate of Samara Luka near Stavropol-on-Volga (now Togliatti) with a water support from 15 to $20 \mathrm{~m}$ according to the project by A.V. Chaplygin (the end of 1930). A counter-project by V.N. Emelyanov has assumed the construction of a dam in Shalang below Kazan, where ground allowed providing a backwater up to $25 \mathrm{~m}$. The third project by the engineers Avdeev and Nikolsky in 1931 suggested the construction of a small (in comparison with the «Big Volga») number of hydro-units, but with great water support. Currently the Volga-Kama cascade is a complex of hydroelectric power stations on the rivers Volga and Kama. It includes 11 large hydro-electric power stations from 28 to 2600
MW, 22 medium-sized power plants up to $28 \mathrm{MW}$ and 12 small ones with a capacity of $0.01-0.5 \mathrm{MW}$ (Krivoshey, 2015). Forests and flood meadows has dominated prior to the water regulation of the Lower Volga in the northern part of the river valley. The southward afforestation declined, and large areas were occupied by open steppe meadows. The situation has changed drastically after a reservoir creation at the south of Saratov. The central floodplain was almost completely flooded and the massifs of lowland meadows disappeared in the upper areas (Fursaev, 1940).

The result of a hydro-electric construction in the 1930s and 1950s was 25,000 square kilometres of flooded floodplains (Krivoshey, 2015). And the deceased desman population was more than $600,000-800,000$ individuals (Onufrenya et al., 2011). The distribution of the desman declined sharply, as its populations survived only at the Volga tributaries.

The desman was a commercial target before the 1920s. And its unregulated fur trade was considered to be the main reduction cause of desman numbers. After limiting the desman harvesting, direct poaching became a limiting factor, but Borodin (1963) considered it to be still significant, but not basic. Nevertheless, as the desman population shrinks, poaching could seize $12-20 \%$ of the available desman number (Khakhin \& Ivanov, 1990).

The change in the political situation, and especially the default in the 1990s, the lack of money in the province, caused that the population survived on the ground mainly by fishing. The emergence of cheap Chinese fishing line networks made poaching the most significant factor in the desman destruction. The animal holds breath under water for several minutes. Later it must rise to surface and breathe. The mesh size of network is not less than $4.5 \mathrm{~cm}$. So a desman has a chance to free itself. But if it gets into a thin fishing line net, it will get confused anyway and die in 5-8 minutes. In addition, fishing line networks abandoned in reservoirs cause the death for many aquatic animals and plants. And their decay kills the animal and plant community. The intensive use of fishing line networks while fishing caused a sharp decline in the Russian desman number in 1990-2010 (Khakhin, 2009).

The two main approaches to the problem of the Russian desman conservation in the early $20^{\text {th }}$ century were applied: to create a network of Reserves, and resettlement of the desman with its acclimatisation in new habitats.

Three specialised Reserves were created to restore the number of the Russian desman (Ok- 
sky Reserve, Khoper Reserve and Klyazminsky Reserve) by the decree of the All-Russian Central Executive Committee and the Council of People's Commissars of the RSFSR «On the Approval of the Network of Complete Reserves of National Significance» of February 10, 1935. The decree declared: «The main objectives of the desman protection are conservation and accumulation of genetic resources of the desman and colonisation of water reservoirs on the territory of the RSFSR, as well as conservation of other economically valuable objects of hunting and commercial fauna on the territory of the reserve.» It was intended to carry out activities aimed at protecting the Russian desman and carrying out work to study it.

Floodplain meadows are valuable agricultural lands. Therefore these territories were attributed as buffer zones around the Reserve's boundaries. Economic organisations were obliged to coordinate their activities with the directorate of the Reserve not to violate the water regime of the floodplains. In several Reserves (for example, Oksky, Prisursky, «Kaluga Zaseki»), the majority of the desman population lives in the protection zone. Currently these territories are not used for their intended purpose. Some lands are privately owned and protection coordination at these territories presents some difficulties.

The period from 1930s to 1970 s was marked by an intensive study of the desman ecology in the Reserves (e.g., Paramonov, 1928; Shaposhnikov, 1933; Krasovsky, 1940; Barabash-Nikiforov, 1950; Aspisov, 1952; Borodin, 1963). However, the method of passive desman protection has not justified itself, according to Borodin (1963). Causes of failure are erroneous overestimation of extermination role, on the one hand, and underestimation of the environment role, on the other hand.

Simultaneously, a large-scale operation was carried out to resettle and acclimatise the desman.

The first desman resettle of more than 3000 individuals took place from 1929 to 1934 . The second attempt of the desman acclimatisation was carried out from 1948 to 1970 . And more than 6000 individuals were relocated. Animals were released to territories of its historical range, and also to Siberia: Bashkir ASSR, Chelyabinsk region, Tomsk region and Novosibirsk region (Pavlov et al., 1973). We know little about their current state. The only information is the registration about 40 burrows of the desman on the right bank of the river Sredniy Toguzak in the Chelyabinsk region in 2007 (Red Data Book of the Chelyabinsk region, 2008).
According to Pavlov et al. (1973), acclimatisation could be successful if the following conditions were met: afforestation of the water coast, logging prohibition, catching nets prohibition and fight against poaching. Flowering of poaching in the 1990s, according to Khakhin (2009), nullified the results of desman acclimatisation.

The Committee for Nature Management was liquidated during a tragic defeat of the country's reserve system in 1951. Two waves of State Reserves closure and a significant reduction in their areas passed between 1951 and 1961. 88 Reserves were closed on the basis of decision of the Council of Ministers of the USSR (August 29, 1951, №3192 «On Reserves»), including Klyazminsky Reserve. Firstly it was divided into several regional sanctuaries, and its territory was joined to the Meshchera National Park in 2011.

98 Reserves with a total area of $329,000 \mathrm{~km}^{2}$ existed in Russia in the late 1990s. The Federal Law «On Protected Areas» was of great importance for nature conservation in Russia in 1995. Currently, the network of Reserves continues to expand (History, 2011). However, there are no Reserves specialised in protection of the Russian desman.

The Protected Areas help to protect desman biotopes and to fight against poaching. However, droughts and lack of floods are significant and negative factors affecting the condition of desman habitats. To protect desman habitats, the Oka State Reserve has attempted to clear and deepen reservoirs (Onufrenya \& Onufrenya, 2016). Deepened and restored reservoirs have proved to be the main places of desman concern in unfavourable conditions in the arid years of 2008-2012.

The creation of a protected desman population in captivity is one of the most important measures for species conservation. Attempts of breeding desman in captivity were undertaken repeatedly, for example, in the Moscow Zoo (Skrebitsky, 1945; Romanov, 1989). A special vivarium was built in the Khoper Reserve to breed desmans, where several generations of researchers have worked on (Krasovsky, 1954; Chichikina, 1983; Karpov, 1992). Krasovsky (1954) has even received one desman brood in captivity. However, it was not possible to repeat the success (according to our information, the pregnant female was caught from nature; the animals have not mated in captivity). The study of the desman behaviour in captivity has started at the Chernogolovka experimental base (A.N. Severtsov Institute of Ecology and Evolution of RAS) since the late 1990s. We have worked out 
the methods for keeping desmans in captivity for a long time (Rutovskaya \& Rozhnov, 2008), but it has not reproduced in captivity yet. And currently there are no methods for breeding it (Rutovskaya \& Makhotkina, 2015).

What do we know about the current state of the Russian desman population?

There are 20 Reserves listing the desman to be a protected species on the Ministry of Natural Resources website (Khakhin, 2011).

The Oka State Nature Biosphere Reserve and the Khopersky State Nature Reserve carry out annual monitoring of the desman population, where there are specialists studying the Russian desman.

In the area of four Protected Areas (Voroninsky State Nature Reserve (Tambov region), Meshchera National Park (Ryazan and Vladimir regions), Ugra National Park (Kaluga region), Pleshcheevo Lake National Park (Yaroslavl region), we have conducted one-time surveys, the results of which will be given below.

Desmans were found in eight reservoirs of four districts of the Republic of Mordovia in 2009 (Andreychev et al., 2009). Three desmans inhabit the Kerzhensky Reserve (Nizhny Novgorod Region), according to the nature chronicle (Bayanov, 2015). It remained from the reintroduced population in 2001-2002. However, acclimatised desmans inhabit the floodplain of the river Kerzhenets from the village Lykovo to the village Rolls in areas adjacent to the Kerzhensky Reserve according to studies of 2012 and 2013 (Bakka et al., 2015).

To restore the desman population ten pairs of animals were released in the National Park «Orel Polesye» in 2002. Desmans have established and distributed along the river Vytebet for several kilometres below up to the village Lgov, according to surveys of 2006 (Onufrenya et al., 2006). The last visual meetings of desman in the Reserve «Kaluga Zaseki» were registered during a water expedition along the river Vytebety near the Muskan tract in 2002 (Chronicle of Nature, 2003). The last meeting with a desman in the Reserve «Nurgush» (Kirov region) was dated in 1998 (Tselishcheva et al., 2013).

The Russian desman is not even mentioned in fauna lists of the national parks «Buzuluksky Bor» (Orenburg and Samara regions) (Animal World, 2008-2015), "Samarskaya Luka» (Samara region) («Samarskaya Luka», 2007-2017) and «Chavash Varmane» (Chuvashia) (Cadastre Data, 2010-2017).

The Russian desman is mentioned as a regional Red Data Book species only in the fol- lowing Protected Areas: Astrakhan Biosphere Reserve (Astrakhan region) (Mammals, 2014), National Park «Mari Chodra» (Republic of Mari El) (Red Data Book, 2014), National Park «Nechkinsky» (Udmurt Republic) (Rare species, 2017), National Park «Khvalynsky» (Saratov region) (Red Data Book, 2009-2015).

Desman populations are also known in Protected Areas that are not listed on the Ministry of Nature's website. In 2005-2008, Desmans were found in 73 water bodies in seven districts of the Lipetsk region along the river Voronezh (Don river basin). But authors have noted that this is the rarest species in the region (Zemlyanukhin, 2009). Forty Russian desmans were introduced to the floodplain of the river Nerussa in the Reserve «Bryansky Les» (Bryansk region) in 2002 and 2003. Desmans have established, according to surveys conducted in 2003-2005. But its abundance remained extremely low (Sitnikova, 2007). Neither a Russian desman nor any sign of their life activities have been found using different techniques in the small tributaries of the river Khoper and river Medveditsa (Saratov region). Nonetheless, we cannot state that this species is absent here (Oparina et al., 2013).

However, we have not obtained any data on desmans during recent years. We should monitor the status of Russian desman populations, as the tendency to reducing of its range and abundance remains. A monitoring of Desmana moschata habitats and a survey of its abundance carried out with the help of volunteers and enthusiasm without targeted state support.

Here we present the results of surveys conducted during 2010-2016. We tried to assess the current status of the Russian desman population. The aim of this study is to draw attention of the scientific community to the catastrophic status of the Russian desman population and to discuss the problems of species conservation.

\section{Material and Methods}

The annual surveys of the Russian desman have been conducted in the Oksky Reserve by M.V. Onufrenya and A.S. Onufrenya. During 2010-2016 one-time surveys of the species populations were conducted in eight regions by the «Club of Russian Desman Friends» (Makhotkina et al., 2013).

Russian desman surveys were carried out according to the method of Borodin (1960). We search the desman burrows along the shoreline from the water. A Desmana moschata burrow has an outlet under the water and it continues with a 
well-defined trench. The inhabited (visited) burrow is distinguished by a hard bottom of trench and absence of silt. Bitten mollusks are the additional evidence of desman's presence. A survey was conducted selectively, taking into account the nature of the coast and the depth of the coastal part. A swampy shore is not suitable for colonisation by desmans, because it has no suitable sites for the burrow construction. Reservoirs with steep banks, overgrown shrubs and littered with tree trunks, as well as with numerous beaver burrows are difficult to survey and refer to the unaccounted ponds. They are considered as potential sites for colonisation by desmans and these are used when extrapolating the desman's abundance.
The size of a desman population has been estimated with relative abundance (population density) (P). We have calculated it as the ratio of burrows number to the surveyed shoreline length. The general desman resource has been calculated by extrapolating of the accounting data to the whole territory: the length of all reservoirs shoreline (L) we have multiplied by the population density $(\mathrm{P})$ and by the recalculation coefficient $\mathrm{K}$. The coefficient $\mathrm{K}$ (number of animals per burrow) varies depending on the month: for August it is equal to 1.26 , for October -0.68 (Borodin, 1963). During 2010-2016, we surveyed 26 territories mainly located within Protected Areas (Table 1, Fig. 2).

Table 1. The studied areas and characteristics of the done work

\begin{tabular}{|c|c|c|c|c|}
\hline Region & Protected Area & Year & $\begin{array}{c}\text { Number of } \\
\text { reservoirs }\end{array}$ & $\begin{array}{l}\text { Total length of the } \\
\text { coastline, } \mathrm{km}\end{array}$ \\
\hline \multirow{15}{*}{ Vladimir region } & Sanctuary «Klyazminsko-Luhsky» & 2010 & 30 & 12.5 \\
\hline & Botanical Sanctuary «Oksko-Coastal» & 2011 & 28 & 15.3 \\
\hline & $\begin{array}{l}\text { Lakes - Nature Monuments of Gorokhovetskiy } \\
\text { district }\end{array}$ & 2012 & 6 & 8.4 \\
\hline & Sanctuary «Klyazminsky coast» & 2012 & 20 & 6.9 \\
\hline & Sanctuary «Kondyrynskaya floodplain» & 2012 & 15 & 1.5 \\
\hline & $\begin{array}{l}\text { Botanical Sanctuary «Oksko-Klyazminskaya } \\
\text { floodplain» }\end{array}$ & 2012 & 26 & 13.2 \\
\hline & Sanctuary «Starodubsky» & 2012 & 8 & 2,5 \\
\hline & Sanctuary «Klyazminsky» & $2012-2014$ & 35 & 10.0 \\
\hline & Sanctuary «Davydovskaya floodplain» & $2013-2014$ & 9 & 5.8 \\
\hline & Botanical Sanctuary «Vyaznikovskaya floodplain» & 2014 & 15 & 7.1 \\
\hline & Hunting farm «Vyaznikovskoe» & 2014 & 6 & 1.9 \\
\hline & Sanctuary «Muromsky» & 2014 & 29 & 20.7 \\
\hline & Meshchera National Park & 2014 & 49 & 14.8 \\
\hline & $\begin{array}{l}\text { Lakes - Natural Monuments of Sudog, Suzdal, } \\
\text { Sobinsky districts and Vladimir }\end{array}$ & 2015 & 18 & 3.3 \\
\hline & Sanctuary «Krutovsky» & 2016 & 15 & 4.7 \\
\hline \multirow{3}{*}{ Ryazan region } & Oka Biosphere Reserve & 2016 & 67 & 26.3 \\
\hline & Hunting farm «Ermishinsky» & 2010 & 59 & 28.0 \\
\hline & Sanctuary «Ryazansky» & 2015 & 21 & 5.0 \\
\hline Kostroma region & Reservoirs of Manturovsky district. & 2011 & 25 & 13.6 \\
\hline Tambov region & Reserve «Voroninsky» & 2013 & 17 & 9.9 \\
\hline Yaroslavl region & Sanctuary «Yaroslavskyi» & 2013 & 3 & 10.0 \\
\hline Kaluga region & National Park «Ugra» & 2013 & 22 & 16.3 \\
\hline \multirow{2}{*}{ Bryansk region } & Reserve «Bryansky Les» & 2014 & 14 & 5.7 \\
\hline & Sanctuary «Kletnyansky» & 2014 & 10 & 7.3 \\
\hline \multirow{3}{*}{ Chuvash Republic } & Reserve «Prisursky» & 2016 & 16 & 7.8 \\
\hline & $\begin{array}{l}\text { Reservoirs of Poretsky, Sumerlinsky and } \\
\text { Yadrinsky districts }\end{array}$ & 2016 & 17 & 7.4 \\
\hline & Total & & $\begin{array}{c}573 \\
\text { reservoirs }\end{array}$ & 265.9 \\
\hline
\end{tabular}




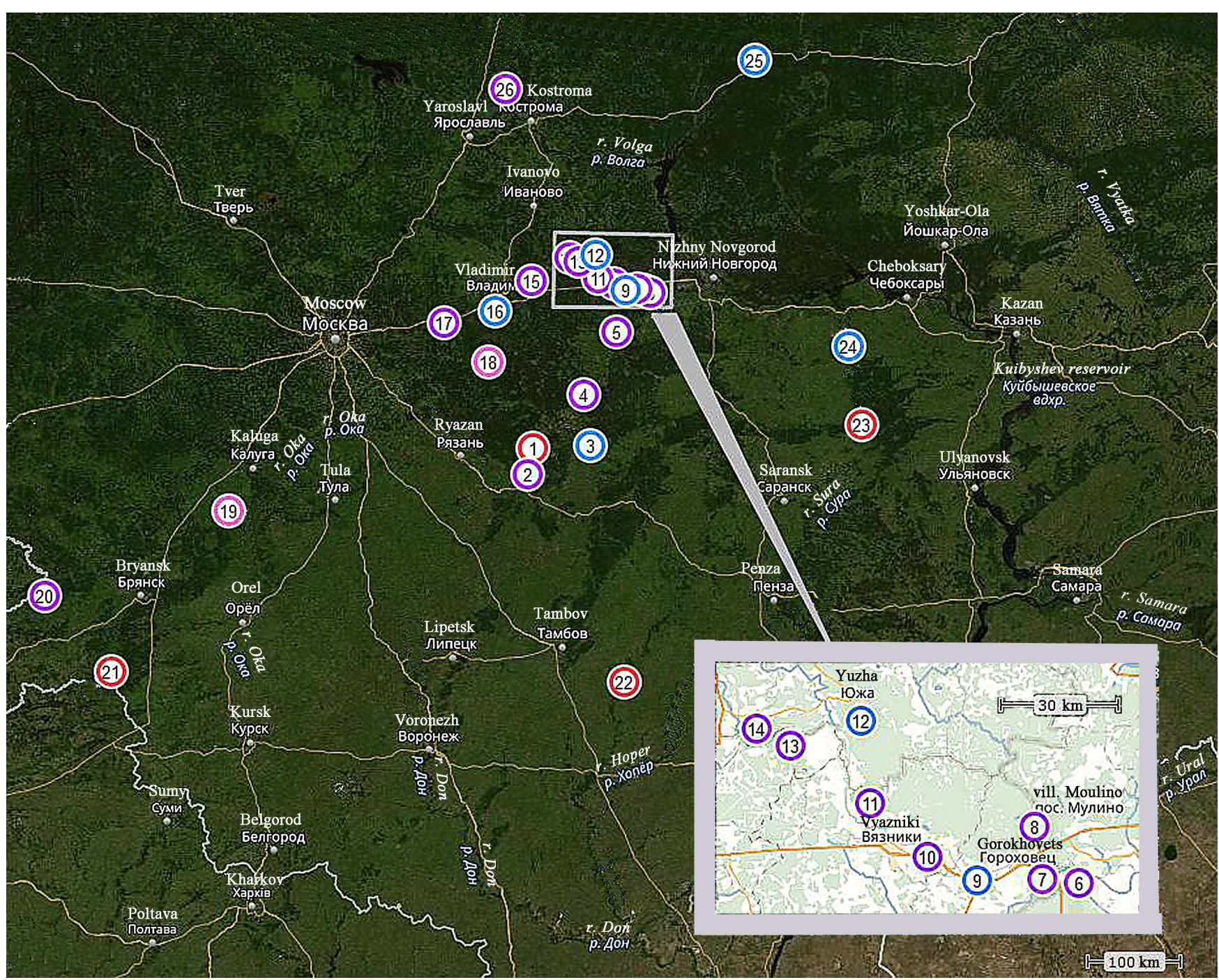

Fig. 2. The locations of the Russian desman populations studied during 2010-2016. Designations: RYAZAN REGION: 1 - Oka Biosphere Reserve; 2 - Sanctuary «Ryazansky»; 3 - hunting farm «Ermishinsky»; VLADIMIR REGION: 4 - Botanical Sanctuary «Oksko-Coastal»; 5 - Sanctuary «Muromsky»; 6 - Botanical Sanctuary «Oksko-Klyazminskaya floodplain»; 7 - Sanctuary «Kondyrynskaya floodplain»; 8- Sanctuary «Klyazminsky coas»«; 9 - Nature Monuments of Gorokhovetskiy district; 10 - Sanctuary «Klyazminsko-Luhsky»; 11 - Botanical Sanctuary «Vyaznikovskaya floodplain»; 12 - hunting farm «Vyaznikovskoe»; 13 - Sanctuary «Klyazminsky»; 14 - Sanctuary «Starodubsky»; 15 - Sanctuary «Davydovskaya floodplain»; 16 - Natural Monuments of Suzdal district, Sudogsky district, Sobinsky district and Vladimir; 17 - Sanctuary «Krutovsky»; RYAZAN REGION:18 - Meshchera National Park; KALUGA REGION: 19 - National Park «Ugra»; BRYANSK REGION: 20 - Sanctuary «Kletnyansky»; 21 - Reserve «Bryansky Les»; TAMBOV REGION: 22 - Reserve «Voroninsky»; CHUVASH REPUBLIC: 23 - Reserve «Prisursky»; 24 - reservoirs of Poretsky, Sumerlinsky and Yadrinsky districts; KOSTROMA REGION: 25 - reservoirs of Manturovsky district; YAROSLAVL REGION: 26 - Sanctuary «Yaroslavskyi». Red circles - State Reserves, violet - Sanctuaries, pink - National Parks, blue - non Protected Areas.

\section{Results}

We have reviewed the results of our surveys, systematising them for river basins and for administrative regions.

The Desman in the Volga river basin. We have conducted surveys in Vladimir region, Ivanovo region, Ryazan region, Kaluga region, Yaroslavl region and Kostroma region which all belong to the Volga river basin. Favourable desman populations are known in Vladimir region. There were 8000 animals in 1985. But the desman number has decreased to 2500 individuals by 2005. Desmans live in the floodplain along of the river Klyazma and the river Oka in this region. Sanctuaries are located on the floodplain almost along both the whole rivers. So it favourably affects the population state. During 2010-2016 we surveyed twelve sanctuaries, one hunting farm, Meshchera National Park and reservoirs - nature monuments of Gorokhovetsky district, Suzdal district, Sudogsky district, Sobinsky district and Vladimir. Such a detailed survey of Vladimir region was carried out due to the active position of the Directorate of Protected Areas in Vladimir region and the National Park «Meshchera». 
We have observed more than $75 \mathrm{~km}$ of the coastline on the floodplain of the river Klyazma. The population density was estimated at 3.1 burrows per $\mathrm{km}$. And the total number of animals was estimated at 1350 individuals. We have passed along $50 \mathrm{~km}$ of the coastline on the floodplain of the river Oka, where the desman population density was estimated at 2.1 burrows per $\mathrm{km}$. The total animal number was evaluated at 750 individuals. Thus, 2000 desmans live in the Vladimir region.

We can find the desman on the floodplains of the tributaries of the river Klyazma: Nerl, Tezi Uvod and Luh in Ivanovo region. By 2000, only 200 animals were found in this area. And desmans have already disappeared in the river Luh and river Teza (Khakhin, 2009). In 2012 we have observed $24 \%$ coastline with a total reservoir length of 27 $\mathrm{km}$. And we found that the desman number is extremely low in the Sanctuary «Klyazminsky». The desman's population density was estimated at 0.5 burrows per $\mathrm{km}$. And the total number of animals was estimated at about 15 individuals.

The largest desman group (about 2600 animals) lives on the floodplains of the Spassk district and Shilovsk district (Izhevsk floodplain) of the Ryazan Region in the Oka State Reserve and in the Ryazansky Sanctuary (Khakhin, 2009). In 2016, 67 water reservoirs of the Oka river floodplain were surveyed with a total length of coastline estimated at $26.3 \mathrm{~km}$ in the Oka State Biosphere Reserve and its buffer zone. The desman number was estimated at 284 individuals.

The desman number declined sharply in the Ryazansky Sanctuary as protection was absence at the beginning of the 21 st century. So, the relative desman number was less than 1 burrow per $\mathrm{km}$ in 2009 (Onufrenya \& Onufrenya, 2012). The desman number was restored after the Sanctuary Ryazansky was attached to the Oka Reserve. We revealed the desman density at 7.2 burrows per $1 \mathrm{~km}$ and the total desman reserve is more than 270 individuals in 2015.

In 2010 we have surveyed the reservoirs with a total length of coastline of $63.2 \mathrm{~km}$ at both banks on the Oka River tributary - river Moksha within the Ermishinsky hunting farm and in the Petelinsky hunting farm territories. The relative desman number was 1.1 burrows per $\mathrm{km}$. And the total species reserve was estimated at 100 individuals. We estimate the total desman number at 1500 individuals in the Ryazan region, taking into account the floodplain lands of the right bank of the river Oka.

The desman number has always been small in the Kaluga region. Originally desmans lived at the floodplain of the river Zhizdra, that is the Oka tributary. There was an attempt to reacclimatise this species in 1959-1960, since the local population had increased up to 1000 individuals. But later it declined again in the 1970s (Khakhin, 2009). The population reached a critical size, when A. Rogulenko, a colleague of the Ugra National Park, could not find any burrows in 2009. However, the desmans have survived at the floodplain of the river Zhizdra, protected by the National Park. And its number began to increase. We have observed reservoirs of the Berezich and Optina forest ranges, where $16.3 \mathrm{~km}$ of coastline were passed. The desman density was estimated at 3.6 burrows per $\mathrm{km}$. And the species reserve was about 400 individuals in 2013.

The northern part of the desman area (upper reaches of the river Volga) is located in Yaroslavl region and Kostroma region. The desman was widespread here until the creation of the Gorky reservoir, which has flooded the river Volga floodplain and mouth of its tributaries (Borodin, 1963). By the beginning of the $21^{\text {st }}$ century, the desman was protected along tributaries of the river Kostroma in the Yaroslavl region and in the middle reaches of the river Unzha and its tributaries. The desman number was estimated at 300 individuals in each region (Khakhin, 2009). In 2011, we observed 25 reservoirs in the middle reaches of the river Unzha in the Manturovsky district. We found only five burrows along the coastline of $29 \mathrm{~km}$. The desman population density was accounted at 0.4 burrows per $\mathrm{km}$. And the total number of animals was estimated at six individuals. Since we have examined $25 \%$ of the Unzha river floodplain, the total desman number was extrapolated at 20-30 individuals. The Sanctuary «Yaroslavsky» is part of the Pleshcheevo Lake National Park. And in 2013 we observed the river Vopsha, river Kast and river Sot with a total coastline length of $75 \mathrm{~km}$. The desman population density was estimated at 1.2 burrows per $\mathrm{km}$. And the total number of animals was estimated at 54 individuals in this region. Thus, the desman number remains low at the northern limit of its range.

Desmans also live in the floodplain of the river Sura middle reaches. The river Sura is the Volga river tributary in the Chuvash Republic. In the 1920s, desmans were common here (Aspisov, 1952). Later (in 2001), the desman became very rare (Khakhin, 2009). In 2016, we found a large desman population in the buffer zone of the Alarsky area of the Prisursky Reserve and in Poretsk district, Shumerlinsky district and Yadrinsky district. We have surveyed $15 \mathrm{~km}$ of coastline and estimated the desman population density at 2.4 
burrows per $\mathrm{km}$. So, the total desman reserve was more than 550 individuals.

The desman in the Don river basin. In 2013, we surveyed the floodplain of the river Vorona (tributary of the river Khoper, Don river basin) in Tambov region. We inspected 17 reservoirs with a total coast line length of $57.5 \mathrm{~km}$. The desman population density was extremely low -0.2 burrows per km. And the total desman number was estimated at ten individuals. As not any desman could be registered for a long period (about 19 years of the Reserve existence), the question whether the desman has survived in this area is of great importance.

The desman in the Dnieper river basin. Only at the beginning of the $20^{\text {th }}$ century, the desman was observed along the river Besed of the Dnieper river basin (Smolensk region and Yekaterinoslavsk district, now Dnepropetrovsk). Desmans were introduced in the river Iput in the Kletnyansky district in 1938 (Borodin, 1963), and in the floodplain reservoirs of the river Nerussa («Bryansky Les» Reserve) in 2002-2003 (Sitnikova, 2007). The desman population has increased and settled along tributaries of the river Oporot, river Nadva and river Voronus but its number was never high. By 2005 , the total reserve of desmans was estimated at 50 individuals. In 2014, we inspected the desman population in the Reserve «Bryansky Les» and in the Sanctuary «Kletnyansky». And we could notice that the desman number actually did not change. The desman has been protected actually in all reservoirs, where it has been noted within the Reserve «Bryansky Les» in 2005, and below along the river Nerussa. We have found 15 burrows while we have surveyed $7.3 \mathrm{~km}$ of the shoreline in the Kletnyansky Sanctuary. Thus, the desman population density was estimated at 2.0 burrows per $\mathrm{km}$. And the total species reserve is $30-40$ individuals. Generally, the desman remains rare in this region.

\section{Discussion}

Summarising, we can estimate the desman population in the surveyed territories of just over 4500 individuals (Table 2). Considering that we surveyed only half of the desman areas, the total desman reserve within the area can be estimated more than $8000-10,000$ individuals.

During 2010-2014, we conducted surveys in seven regions of Russia, mainly within the historical desman range. The desman reserve was estimated at 6000 individuals in 2014, and a weak tendency to the growth of desmans' number was noted by Rutovskaya et al. (2014).
Table 2. Relative numbers of desmans and its total reserve by results of surveys in 2010-2016

\begin{tabular}{|c|c|c|}
\hline Region & $\begin{array}{l}\text { Population density, } \\
\text { burrows / km }\end{array}$ & $\begin{array}{c}\text { Desman } \\
\text { reserve, } \\
\text { individuals }\end{array}$ \\
\hline \multicolumn{3}{|c|}{ Volga river basin } \\
\hline Vladimir region & 2.7 & 2000 \\
\hline Ivanovo region & 0.5 & 15 \\
\hline Ryazan region & 3.3 & 1500 \\
\hline Kaluga region & 3.6 & 400 \\
\hline Kostroma region & 0.4 & 25 \\
\hline Yaroslavl region & 1.2 & 55 \\
\hline Chuvash Republic & 2.4 & 550 \\
\hline \multicolumn{3}{|c|}{ Don river basin } \\
\hline Tambov region & 0.2 & 10 \\
\hline \multicolumn{3}{|c|}{ Dnieper river basin } \\
\hline Bryansk region & 1.7 & 50 \\
\hline Total & & 4600 \\
\hline
\end{tabular}

Our surveys in the Vladimir region, Ryazan region and the Chuvash Republic in 2014-2016 suggest that the desman population begins to recover. In 2013 desmans were found in almost every second reservoir of the Zhizdra river floodplain in the National Park «Ugra». So, the population has increased significantly during 3-4 years compared to 2008-2009 when it practically disappeared from the Protected Area territory (personal communication of A.V. Rogulenko). By 2015, a significant increase of the population was noted in the Ryazan Reserve in the Oka river floodplain, compared to 2009. So, the desman number has increased by seven times. In 2016, we found large desman populations of more than 500 individuals in the Prisursky Reserve and in the floodplain downstream of the Sura river. Although the latest surveys in Chuvashia in 2001 revealed only twelve individuals in the Shumerlinsky district. In 2015-2016, we found a high density of the population (15.2 burrows per $\mathrm{km}$ ) in the Davydovsky and Krutovsky sanctuaries and in lakes - nature monuments of Vladimir region along the upper course of the river Klyazma. That can be considered as a very high current state of the desman population.

Some adaptation of the desman behaviour to anthropogenic pressure may be a reason of the species' state improving over the last 3-4 years: e.g., its secretive behaviour, great depth of outcrops occurrence under silt layer. In addition, protection has become tougher in Protected Areas of many regions, which affect the general desman popula- 
tion state. Nevertheless, some stabilisation of the population state is observed.

However, we note an unchanged decrease in the desman number compared with that over the last 50 years. The rate of contraction of the desman population has doubled during the last 15 years (Fig. 3). So $70 \%$ of the population has been lost during this period.

Poaching and unfavourable climatic conditions are the main reasons for this catastrophic decline in the desman reserve over the last 15 years (from 2001 to 2016). As noted above, the desman multiplies if flood in spring has an average level (Rutovskaya et al., 2012). We suggest that the desman population came to the brink of extinction as mortality exceeded offspring due to absence of spring floods and a number of arid hot years in 2008-2012. We can demonstrate it by the example of the Oka State Nature Reserve: the desman number declined by seven times over these years in the Protected Area. And only with the resumption of floods it began to recover slowly in 2013 (Fig. 4).

Thus, there is a threat of complete extinction in the case of long-term climatic unfavourable conditions in the current critical desman population state.

Contrariwise the opinion of Borodin (1963) who does not consider poaching as a serious limiting factor, we think that poaching came to the fore on localities at the end of the 20th century and the beginning of the 21 st century, due to the society destabilisation. So, the role of Protected Areas in the conservation of the Russian desman is significant. We can demonstrate it with the following example (Fig. 5).
The State Nature Sanctuary «Ryazansky» was established on 29 June 1987 in the Spassk district near the village Izhevskoye by the decision of the Ryazan region Executive Committee and had federal subordination. In 2000, the hunting farm «Erakhturskoe» was founded on the opposite bank of the river Oka by the resolution of the administration head of the Ryazan region (№792 on 1 December, 2000). Thus, the first surveys were conducted in the sanctuary Protected Area in 1999 and in the unprotected territory of the Yerakhtursky district. The desman population density was higher in the Protected Area. The Ryazansky Sanctuary was almost not protected because of a lack of funding at the beginning of the 2000s, whereas a strict protection system was established in the newly formed hunting farm. The desman number in the Sanctuary has fallen during ten years, compared with that at the hunting farm where it has grown significantly. The Sanctuary «Ryazansky» territory protection was entrusted to the Oka State Reserve in accordance with the Order №71 of 26 March 2009 of the Ministry of Natural Resources and Ecology of the Russian Federation. The protection organised after 2009 has led to a significant increase of the desman number.

Thus, currently the passive protection of desman habitats and anti-poaching activity in Protected Areas are actually the only measures to protect this relic species. If we will further ignore the catastrophic state of Russian desman, it can lead to its complete loss as a result of long-term adverse climatic conditions or a next society destabilisation.

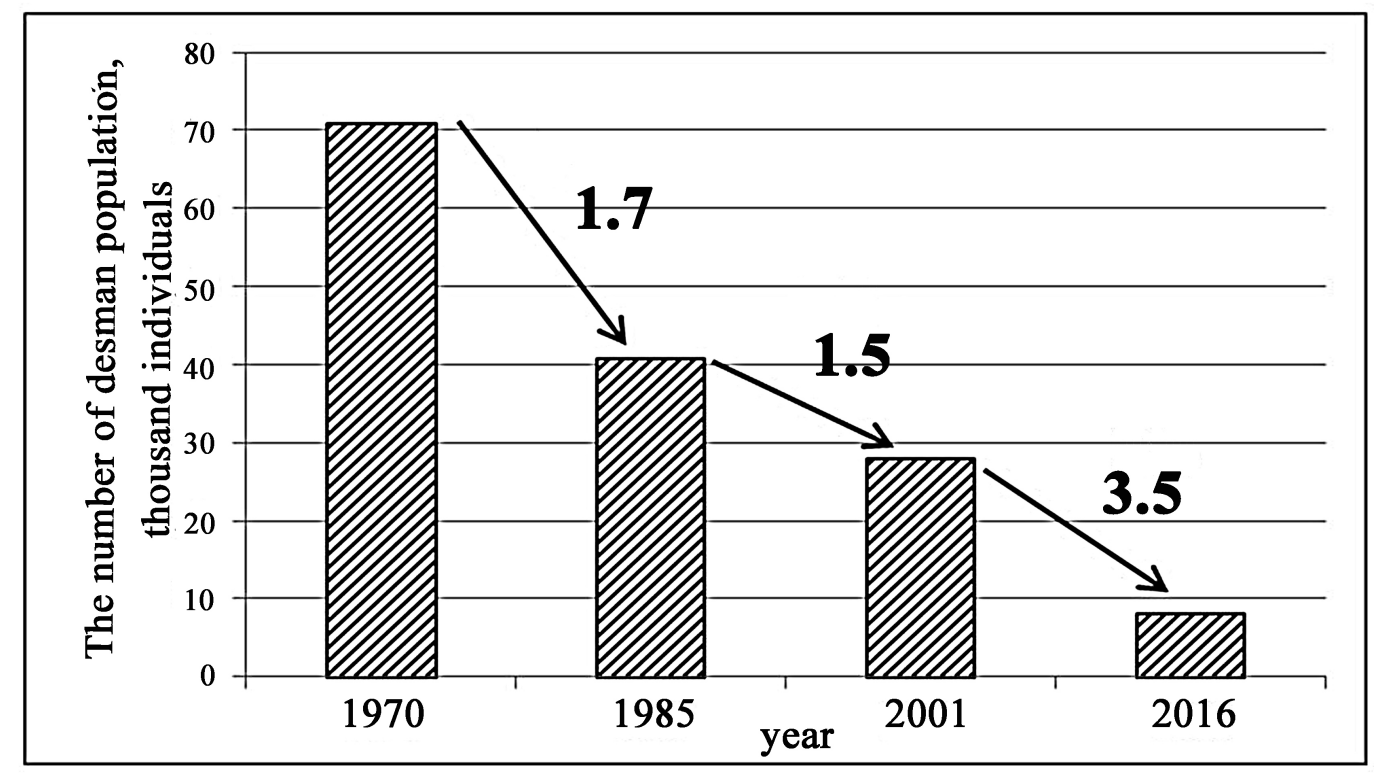

Fig. 3. The total Russian desman reserve changes during the last 50 years. Numbers alongside the arrows show how many times the desman number has decreased over a period of 15 years. Data for 1970, 1985 - according to Khakhin \& Ivanov, 1990. Data for 2001 - according to Khakhin, 2009. 


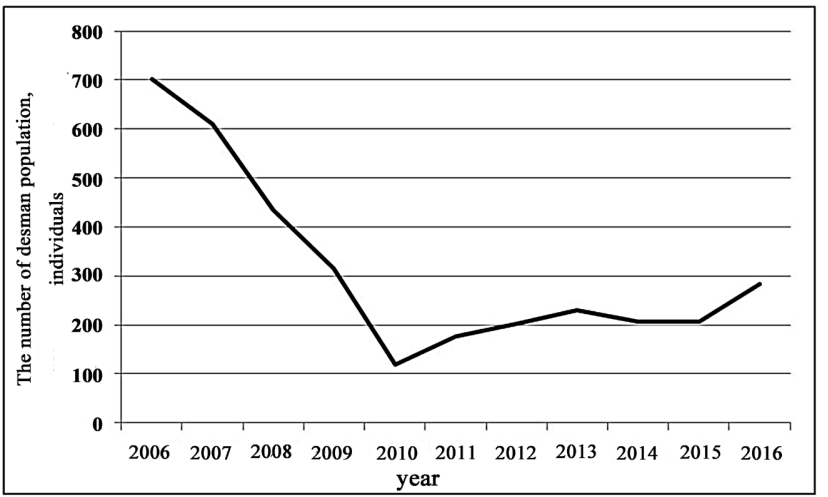

Fig. 4. Dynamics of Russian desman number in the Oka State Nature Biosphere Reserve during the last 10 years.

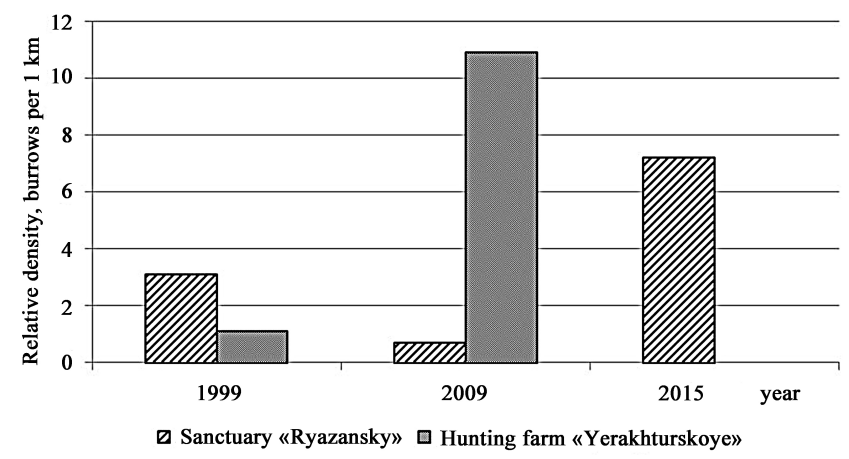

Fig. 5. The desman population density in the Sanctuary «Ryazansky» and on the private hunting farm «Yerakhturskoye» over the last 15 years.

In this regard, we have formulated a few recommendations that we need to address the problem of Russian desman protection.

1. It is necessary to transferee the Russian Federation Red Data Book status of Desmana moschata towards $1-$ species under threat of extinction. It is necessary to develop a strategy of species conservation and to achieve state support for realising this strategy.

2. It is necessary to monitor and study Russian desman populations in Protected Areas within the Russian desman historical range. It is necessary to conduct regular internships for huntsmen and staff to study Russian desman surveys.

3 . Russian funds are to encouraged investigations of the Russian desman by scientific departments of federal Protected Areas with targeted grants.

4. It is necessary to get state support for hunting farms that carry out the Desmana moschata monitoring and conservation measures in their territories.

5. It is necessary to include buffer zones, where desmans live, into the Protected Areas borders. It will allow us to provide more effectively the Russian desman protection.

\section{Acknowledgments}

The authors are very grateful to the «Club of Russian Desman Friends» whose members have help unselfishly: Ph.D. N.R. Zaripova, K.A. Eskova, A.S. Igoshin, Yu.O. Moreva, A.E. Kabychnova, S.A. Buynitskaya, I.A. Popov, A.A. Kosinsky, M. Prokhorova, M.A. Sergeyev, Ph.D. E.A. Vanisova, M.A. Shcherbayeva, M.S. Kuzmina, E.A. Voronin, T.V. Maksimova, A.A. Krylovich, A.S. Soboleva, M.A. Berezhnoy, C.I. Akimov, M.N. Sokolova, M.A. Zhulina, O.N. Vorobyeva, A.Yu. Terentyev, N. Orfenov. We express our gratitude for a warm welcome and assistance in conducting the surveys to the staffs of the federal Protected Areas, sanctuaries and hunting farms where we have worked.

\section{References}

Aidarov I.P. 2006. Essays on the history of irrigation development in the USSR and Russia. Moscow: MGUP Publishing House. 269 p. [In Russian]

Andreychev A.V., Kuznetsov V.A., Lapshin A.S., Grishutkin G.F. 2009. Preliminary materials about distribution of Russian desman (Desmana moschata L.) in the Republic of Mordovia. In: Rare animals of the Republic of Mordovia: materials for the Red Data Book of the Republic of Mordovia for 2009. Saransk: Publisher of Mordovia State University. P. 4-7. [In Russian]

Animal World. In: National Park «Buzuluksky Bor». 2008-2015. Available at: http://buzulukskiybor.ru/menu/ o-nas/zhivotnyij-mir. Retrieved on 22 April, 2017.

Aspisov D.I. 1952. Desman. Moscow: Zagotizdat. 48 p. [In Russian]

Bakka S.V., Kiseleva N.Yu., Odrova L.N. 2015. Vertebrate animals of the Kerzhensky Reserve (annotated list). Proceedings of the State Nature Biosphere Reserve «Kerzhensky» 7: 6-59. [In Russian]

Barabash-Nikiforov I.I. 1950. Beaver and desman as the components of water-shore complex. Voronezh: Voronezh State University. 107 p. [In Russian]

Bayanov N.G. 2015. Fauna and Animal Population. In: Chronicle of Nature of the Kerzhensky State Reserve. Book 22. Nizny Novgorod, (Manuscript, SNBR «Kerzhensky»). Available at: http://www.kerzhenskiy.ru/ upload/biblioteka/letopis/2015/8 Фауна и животное население_2015.pdf. [In Russian]

Borodin L.P. 1960. Instructions about survey and resettlement of desman. Saransk: Mordovia Book Publishing House. 18 p. [In Russian]

Borodin L.P. 1963. Russian desman. Saransk: Mordovia Book Publishing House. 301 p. [In Russian]

Borovitsky P.I. (ed.). 1951. A brief reference book for teachers about natural science. Leningrad: Uchpedgiz of the RSFSR. 674 p. [In Russian]

Cadastre Data. In: National park «Chavash Varmane». 2010-2017. Available at: http://npark21.ru/o-parke/kadastre/. Retrieved on 22 April, 2017.

Chichikina S. 1983. Desman in captivity. Hunting and hunting economy 2: 8-9. [In Russian]

Chronicle of Nature of the Reserve «Kaluga Zaseki» for 2002. Book 9. Ulyanovo, 2003. Available at: http://zaseki.ru/userfiles/files/letopis2002.pdf. [In Russian] 
Fursaev A.D. 1940. Investigation of flora and vegetation of the Lower Volga valley. Doctoral thesis. Saratov: Saratov State University. 559 p. [In Russian]

History. In: Protected Areas of Russian Federation. Ministry of Natural Resources, 2011. Available from: http://www. zapoved.ru/main/history. Retrieved on 22 April, 2017

Karpov N.A. 1992. The long keeping of desman in captivity In: First all-union conference on the biology of insectivorous mammals. Moscow. P. 78-79. [In Russian]

Kennerley R., Turvey S.T. 2016. Desmana moschata. In: The IUCN Red List of Threatened Species 2016: e.T6506A22321477. Available at: http:// dx.doi.org/10.2305/IUCN.UK.2016-2.RLTS. T6506A22321477.en. Downloaded on 22 April 2017.

Khakhin G.V. 2009. Russian desman in danger: Dynamics of numbers and problem of protection. Moscow: Publishing House of the Biodiversity Conservation Centre. 104 p. [In Russian]

Khakhin G.V. 2011. Russian Desman. In: Protected Areas of Russian Federation. Ministry of Natural Resources. Available from: http://www.zapoved.ru/species/272/\%D0\%A0\%D1 $\% 83 \% \mathrm{D} 1 \% 81 \% \mathrm{D} 1 \% 81 \% \mathrm{D} 0 \% \mathrm{BA} \% \mathrm{D} 0 \% \mathrm{~B} 0 \% \mathrm{D} 1 \% 8 \mathrm{~F} \%$ D0\%B2\%D1\%8B\%D1\%85\%D1\%83\%D1\%85\%D0\%BE $\% \mathrm{D} 0 \% \mathrm{BB} \% \mathrm{D} 1 \% 8 \mathrm{C}$. Retrieved on 22 April, 2017.

Khakhin G.V., Ivanov A.A. 1990. Desman. Moscow: Agropromizdat. 191 p. [In Russian]

Kolpakov V.V., Sukharev I.P. 1981. Agricultural melioration. Moscow: Kolos. 328 p. [In Russian]

Krasovsky V.P. 1940. Materials on the ecology of the desman. In: Proceedings of the Khoper State Reserve 1: 3-66. [In Russian]

Krasovsky V.P. 1954. Observations on the reproduction of the desman in captivity. Zoologicheskii Zhurnal 33(1): 180-207. [In Russian]

Krivoshey V.A. 2015. The Volga River (problems and solutions). Moscow: "Zhurnal "RT"». 92 p. [In Russian]

Kulagin N.M. 1922. Russian fur trade. Petrograd: M. \& S. Sabashnikov. 58 p. [In Russian]

Kuznetsov B.A. 1932. Commodity of fur and fur raw material of the USSR. Mocsow: Sovetskaya Asia. 464 p. [In Russian]

Makhotkina K.A., Zaripova N.R., Kabychnova A.E., Kosinsky A.A., Moreva Yu.O., Onufrenya A.S., Onufrenya M.V., Popov I.A., Rutovskaya M.V., Sergeev M.A. 2013. Contribution of informal public associations to the solution of scientific-practical problems of nature conservation (on example of the «Club of Russian Desman Friends»). In: Protected Areas and Objects of Vladimir region and adjacent regions. Vladimir. P. 175-177. [In Russian]

Mammals. In: Astrakhan Biosphere Reserve. 2014. Available at: http://astrakhanzapoved.ru/PRIVATE/fauna/\#mleko. Retrieved on 22 April, 2017.

Okulova N.M., Onufrenya A.S., Onufrenya M.V. 2008. Analysis of monitoring data on the Russian desman (Desmana moschata) in the Oka state biosphere reserve in relation to the problem of species' population decline. Russian Journal of Ecology 39 (7): 510-515.

Onufrenya A.S., Onufrenya M.V. 2012. Russian desman number and location in the Spassky and Shilovsky districts at Ryazan region in 2008-2009. In: Proceedings of the Oka Reserve. Ryazan 27: 100-113. [In Russian]
Onufrenya A.S., Onufrenya M.V. 2016. Russian desman in Oka basin. Proceedings of the Oka State Natural Biosphere Reserve 37: 1-204. [In Russian]

Onufrenya A.S., Vyshegorodsky N.V., Onufrenya M.V. 2006. Russian desman in NP «Orlovsky Polesye». In: Materials of inventory of water mammals inhabiting territory of the state national park «Orlovsky Polesye». Orel. P. 43-45. [In Russian]

Onufrenya A.S., Onufrenya M.V., Makhotkina K.A., Moreva Yu.O., Rutovskaya M.V. 2011. Current status of Russian desman population. In: Teriofauna of Russia and adjacent territories. Moscow. P. 347. [In Russian]

Oparina O.S., Filinova E.I., Sonina E.E., Oparin M.L. 2013 Current status of the Russian desman habitats in small rivers of the Don River Basin in Saratov oblast and the abundance of this species. Biology Bulletin 40(10): 854-861.

Paramonov A.A. 1928. About the biology of desman. In: Proceedings on study of Reserves 9: 5-34. [In Russian]

Pavlov M.V., Korsakova I.B., Timofeev V.V., Safonov V.G. 1973. Desman. In: Acclimatisation of the hunting and commercial animals and birds in the USSR. Part 1. Kirov: The Volga-Vyatka Book Publishing House. P. 9-47. [In Russian]

Pidoplichko I.G. 1951. On the glacial period. Vol. 2. Kiev: The Academy of Sciences of the Ukrainian SSR. 263 p. [In Russian]

Rare species: the species' list of the national park included in the Red Data Book of the Udmurt Republic. In: $\mathrm{Na}$ tional park «Nechkinsky». 2017. Available at: http:// nechkinsky.ru/red.html. Retrieved on 22 April, 2017.

Red Data Book of Russian Federation (Animals). Moscow: Astrel, 2001. 860 p. [In Russian]

Red Data Book of the Chelyabinsk region. In: Ministry of Radiation and Ecological Safety of Chelyabinsk region. Available at: http://igz.ilmeny.ac.ru/RED_BOOK/m jiv_mlek_nasekomoiad_rusvihuhol_01.html. Retrieved on $29.03 . \overline{2} 017$. [In Russian]

Red Data Book of the USSR. Moscow: Lesnaya promyshlennost, 1978. 460 p. [In Russian]

Red Data Book. In: National park «Mariy Chodra». 2014. Available at: http://mariy-chodra.ru/nauka/krasnajakniga/. Retrieved on 22 April, 2017.

Red Data Book: data on rare and endangered species of animals and plants. In: National Park «Khvalynsky». 2009-2015. Available at: http://nphvalynskiy.ru/bioraznoobrazie/krasnaya-kniga. Retrieved on 22 April, 2017. [In Russian].

Romanov P.N. 1989. Desman in the Moscow Zoo. In: Problems of domestication of animals. Moscow: Nauka. P. 173-177. [In Russian]

Rutovskaya M.V., Rozhnov V.V. 2008. Experience in keeping and breeding Russian desman (Desmana moschata L.) in captivity. Scientific research in zoological parks 24: 77-102. [In Russian]

Rutovskaya M.V, Makhotkina K.A. 2015. I want leave to nature! Or why does Russian desman do not breed in captivity? Scientific research in zoological parks 31: 89-103. [In Russian]

Rutovskaya M.V., Onufrenya M.V., Onufrenya A.S. 2012. Role of floods at Russian desman life. In: Protected Areas and Objects of the Vladimir region and adjacent regions. Vladimir. P. 147-151. [In Russian] 
Rutovskaya M.V., Vanisova E.A., Zaripova N.R., Kabychnova A.E., Kosinsky A.A., Makhotkina K.A., Moreva Yu.O., Onufrenya A.S., Onufrenya M.V., Popov I.A., Sergeev M.A. 2014. Current status of Russian desman population at territory of the historical range - results of research during last 5 years. In: Protected Areas and Objects of Vladimir region and adjacent regions. Vol. 3. Vladimir. P. 86-93. [In Russian]

Rzebik-Kowalska B. 2006. Erinaceomorpha and Soricomorpha (Mammalia) from the Late Pleistocene and Holocene of Krucza Skala Rock Shelter and Komarowa Cave (Poland). Acta Zoologica Cracoviensia. Series A Vertebrata 49 (1): 83-118.

Samarskaya Luka. 2007-2017. Available at: http://www. npsamluka.ru/. Retrieved on 22 April, 2017.

Shaposhnikov L.V. 1933. Desman. Moscow; Leningrad: Vneshtorgizdat. 208 p. [In Russian]
Shaposhnikov L.V. 1938. Restoration of desman number. Journal of Hunting trade 1.

Sitnikova E.F. 2007. The results of desman reacclimatisation in the «Bryansky Les» Reserve. In: The study and protection of biological diversity of the Bryansk region 3: 115-120. [In Russian]

Skrebitsky G.A. 1945. Desman. Moscow: Moscow Zoo Print. 50 p. [In Russian]

Smirnov N.G., Ponomarev D.V. 2007. News about the Past Distribution of the Desman (Desmana moschata L.) Doklady Biological Sciences 414: 219-220.

Tselischeva L.G., Tarasova E.M., Lachokha E.P., Kondrukhova S.V., Shubin S.E. 2013. Rare species of «Nurgush» site of the «Nurgush» reserve. In: Proceedings of the State Nature Reserve «Nurgush» 2: 141-164. [In Russian]

Zemlyanukhin A.I. 2009. Russian desman in the Lipetsk region. Lipetsk: Publisher of the Lipetsk State Pedagogical University. 104 p. [In Russian]

\title{
РУССКАЯ ВЫХУХОЛЬ (DESMANA MOSCHATA: TALPIDAE) НА ГРАНИ ИСЧЕЗНОВЕНИЯ
}

\author{
М. В. Рутовская ${ }^{1}$, М. В. Онуфреня ${ }^{2}$ А. С. Онуфреня² \\ ${ }^{1}$ Институт проблем экологии и эволюичи имени А.Н. Северцова РАН, Россия \\ ${ }^{2}$ Окский государственный природный биосферный заповедник, Россия \\ e-mail:desmana@yandex.ru
}

\begin{abstract}
Популяция русской выхухоли на всей территории ее исторического ареала составляет в настоящее время не более 8000-10000 особей. Оценка численности популяции русской выхухоли основана на прямых учетах в течение 2010-2016 гг. Было обследовано более 266 км береговой линии в 8 областях исторического ареала выхухоли. Начиная с начала XX в. численность вида неуклонно сокращается. Кроме уже описанных ранее факторов, определяющих сокращение численности вида, таких как мелиорация, строительство гидростанций и расцвета браконьерства в конце прошлого века, на состояние популяций русской выхухоли неблагоприятно сказывается изменение климата, выражающегося в периодических засухах и отсутствие паводков. Заповедные территории в настоящий момент остаются единственной пассивной мерой по сохранению русской выхухоли в условиях отсутствия программы по сохранению вида и государственной поддержки.
\end{abstract}

Ключевые слова: животные из Красной книги, заповедное дело, русская выхухоль 